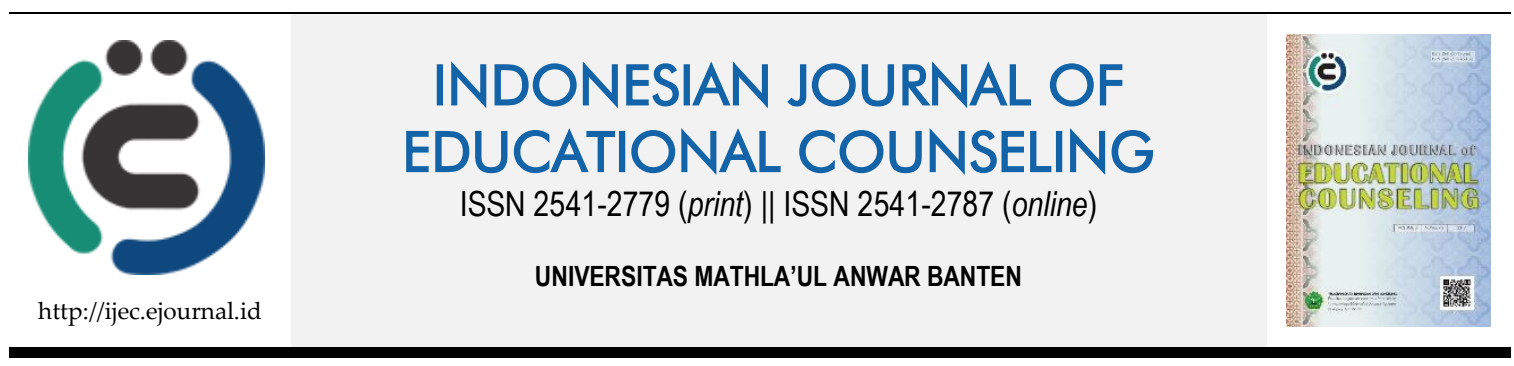

Research Based Article

\title{
Kompetensi Sosio-Emosional Peserta Didik Berbakat dalam Setting Pendidikan Inklusi
}

\author{
Eka Sakti Yudha ${ }^{1}$, Azni Nurul Fauzia ${ }^{2}$, Nandang Rusmana ${ }^{3}$ \\ 1, 2,3 Universitas Pendidikan Indonesia
}

\begin{tabular}{ll}
\hline Article History & ABSTRACT \\
\hline Received: 25.03.2019 & SOCIO-EMOTIONAL COMPETENCIES OF STUDENTS IN THE INCLUSIVE \\
01.04 .2019 & EDUCATION SETTING. The study aims to know the level of emotional-social \\
Accepted: 10.04 .2019 & competencies of gifted students and their implications for the program of \\
Available online: 05.08 .2019 & appropriate personal-social guidance services to help gifted students improve \\
& emotional-social competence. Descriptive research methods were chosen to \\
& provide an overview of the phenomena that occur in the field. The research was \\
& carried out at Bandung Public High School 4 with the first high school \\
& background to carry out inclusive education. The sampling process is done by \\
& purposive sampling approach, with the meaning of the sample in the study \\
& selected based on predetermined criteria, namely based on the level of \\
& intelligence, creativity, and endurance of students who are above the average \\
& ability of students in general. The number of samples involved in the study \\
& amounted to 39 gifted students of class X in the academic year 2015/2016. \\
& Research to measure students' emotional-social competencies in addition to \\
& involving personal assessment, also involves peers and teachers who know \\
& gifted students. The results showed that the social-emotional competencies of \\
& gifted students were generally at the level of competency or were on average \\
& abilities based on personal, peer, and teacher ratings. Also, the results of the \\
& research were used as the basis for the preparation of a personal social program. \\
& The results of the program validation test show that the design of the program \\
& is considered feasible to implement.
\end{tabular}

KEYWORDS: Emotional-Social Competence, Gifted, Personal-Social Guidance And Counseling Programs.

DOI: $10.30653 / 001.201933 .103$

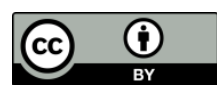

This is an open access article distributed under the terms of the Creative Commons Attribution 4.0 International License, which permits unrestricted use, distribution, and reproduction in any medium, provided the original work is properly cited. @ 2019 Eka Sakti Yudha, Azni Nurul Fauzia, Nandang Rusmana.

\section{PENDAHULUAN}

Kompetensi emosional-sosial merupakan seperangkat kemampuan individu yang akan membantu individu berpandangan dan bertindak pada lingkungan sosial. Kompetensi emosional-sosial sangatlah diperlukan, karena akan membantu individu memperoleh pemenuhan kebutuhan perkembangan individu. Surya (2003) menyebutkan 
bahwa apabila individu merasa kesulitan daalam berhubungan dengan diri atau dengan orang lain atau kedua-duanya, dapat menganggu pemenuhan kebutuhan. Jika hal tersebut tidak diperhatikan, dapat menyebabkan gangguan-gangguan psikologis.

Peserta didik berbakat kelas $\mathrm{X}$ selain dihadapkan pada kondisi penyesuaian terhadap lingkungan sekolah baru juga dihadapkan pada ekspektasi lingkungan sekitar peserta didik terhadap pencapaian prestasi individu. Hal ini dapat menjadi tantangan bagi peserta didik berbakat dalam menyesuaikan diri dan merasa diterima oleh lingkungan sekitar peserta didik.

Peserta didik berbakat yang didefinisikan oleh Renzulli adalah individu yang dikategorikan memiliki kemampuan di atas rata-rata pada tingkat kognitif, kreatifitas, dan komitmen dalam mengerjakan tugas (Callahan \& Miller, 2005). Kemampuan intelektual yang tinggi pada remaja berbakat mampu membuat kelompok berbakat menampilkan dirinya secara normatif atau bahkan lebih unggul sebagai penyesuaian psikososial dibandingkan kelompok remaja tidak berbakat (Džinović, Đević, \& Đerić, 2019). Studi Howley \& Pendarvis di tahun 1995 menunjukkan korelasi positif antara berbakat dengan kemajuan secara sosial dan emosional (Gallagher, Smith, \& Merrotsy, 2011), peserta didik berbakat setidaknya memiliki penyesuaian diri yang baik dan matang, dalam beberapa kasus peserta didik berbakat diidentifikasi memiliki perkembangan emosional-sosial yang lebih matang (Gallagher, Smith, \& Merrotsy, 2011; Clark, 2008; Neihart, 1999). Di sisi lain peserta didik berbakat diklaim memiliki kondisi rentan terhadap risiko masalah emosional-sosial selama masa-masa kritis perkembangan mereka (Džinović, Đević, \& Đerić, 2019).

Salah satu fenomena permasalahan emosional-sosial yang dihadapi oleh peserta didik berbakat ditunjukkan pada studi yang dilakukan di Hungaria oleh Mirnics (2013) kepada 100 remaja yang diidentifikasi berbakat. Hasil temuan Mirnics dan tim bahwa dari 100 orang peserta ditemukan sebanyak $43 \%$ mengalami permasalahan emosional di tingkat tinggi; $46 \%$ mengalami permasalahan emosional di tingkat menengah, dan sebanyak $11 \%$ mengalami permasalahan emosional di tingkat rendah. Sedangkan pada permasalahan sosial, sebanyak $56 \%$ mengalami permasalahan sosial di tingkat tinggi, 31\% mengalami permasalahan sosial di tingkat menengah, dan $13 \%$ mengalami permasalahan sosial di tingkat rendah.

Selain penelitian Mirnics, penelitian lainnya menemukan bahwa peserta didik berbakat dihadapkan pada kondisi-kondisi rentan yang dapat mempengaruhi penyesuaian diri mereka, seperti pandangan peserta didik kelas reguler kepada peserta didik di kelas akselarasi, yang memandang bahwa peserta didik di kelas akselarasi cenderung bersikap arogan (Herrmann \& Nevo, 2011). Pada studi oleh lain, Choate dan Bliss (2006 dalam Gallagher, Smith, \& Merrotsy, 2011) meneliti persepsi guru pada peserta didik berbakat, yang sbeagian besar percaya bahwa peserta didik berbakat memiliki risiko yang lebih besar untuk menghadapi masalah emosional, stres, dan menjalin hubungan peserta didik lainnya. L. J Coleman dan Cross (1988) menekankan bahwa persepsi atau stigma kepada peserta didik berbakat tentang kemampuan mereka memiliki efek nyata pada interaksi sosial mereka dengan orang lain.

Proses penelitian yang dilaksanakan di SMA Negeri 4 Bandung menemukan peserta didik berbakat berjumlah 39 orang yang tersebar ke dalam tujuh kelas. Berdasarkan studi pendahuluan yang dilakukan, dari pantauan guru BK belum diketahui karakteristik 
khusus dari kompetensi emosional-sosial peserta didik berbakat serta kebutuhan yang diperlukan mereka dalam mendukung kebutuhan pengembangan diri. Selain itu berdasarkan hasil temuan, layanan Bimbingan dan Konseling di SMA Negeri 4 Bandung belum menyediakan layanan atau program khusus yang diperuntukan bagi peserta didik berbakat.

Fenomena yang terjadi berdasarkan penelitian sebelumnya, menjadi dasar dalam penelitian untuk mengetahui bagaimana kompetensi emosional-sosial peserta didik berbakat kelas X di SMA Negeri 4 Bandung, dan mengetahui bagaimana implikasinya terhadap penyusunan program bimbingan dan konseling bagi pemenuhan kebutuhan peserta didik berbakat, karena seyogyanya layanan diberikan kepada seluruh peserta didik berdasarkan kebutuhan pengembangan diri mereka serta tidak diskriminatif.

Hal ini diatur pada prinsip layanan Bimbingan dan Konseling dalam Peraturan Menteri Pendidikan dan Kebudayaan Republik Indonesia Nomor 111 Tahun 2014 tentang Bimbingan dan Konseling pada Pendidikan Dasar dan Pendidikan Menengah. Pasal 5 mengenai Prinsip Layanan Bimbingan dan Konseling, yaitu. Pada Pasal 5 mengenai prinsip layanan Bimbingan dan Konseling, program Bimbingan dan Konseling Pribadi Sosial bagi peserta didik berbakat berusaha memenuhi prinsip layanan; 1) diperuntukkan bagi semua dan tidak diskriminatif; 2) merupakan proses individuasi; 3) menekanan pada nilai yang positif; 4) merupakan tanggung jawab bersama; 5) mendorong Konseli untuk mengambil dan merealisasikan keputusan secara bertanggung jawab; 6) berlangsung dalam berbagai latar kehidupan; merupkan bagian integral dari proses pendidikan; 7) dilaksanakan dalam bingkai budaya Indonesia; 8) bersifat fleksibel dan adaptif serta berkelanjutan; 9) dilaksanakan sesuai standar dan prosedur profesional Bimbingan dan Konseling; dan 10) disusun berdasarkan kebutuhan Konseli.

\section{METODE}

Pendekatan yang digunakan dalam penelitian ini adalah pendekatan kuantitatif yang dipilih arena penelitian ditujukan untuk menguji atau memverifikasi penjelasan mengenai kompetensi emosional-sosial peserta didik berbakat. Metode penelitian yang digunakan adalah metode deskriptif yang bertujuan untuk menggambarkan tingkat kompetesni emosional-sosial peserta didik berbakat kelas X SMA Negeri 4 Bandung Tahun Ajaran 2015-2016. Proses sampling dilakukan dengan pendekatan purposif sampling, dengan arti sampel dalam penelitian dipilih berdasarkan kriteria yang telah ditentukan, yaitu berdasarkan tingkat kecerdasan, kreativitas, dan daya tahan peserta didik yang di atas rata-rata kemampuan peserta didik pada umumnya. Jumlah sampel yang dilibatkan pada penelitian berjumlah 39 peserta didik berbakat kelas $\mathrm{X}$ tahun ajaran 2015/2016.

Instrumen yang digunkan dalam penelitian adalah instrumen yang dikembangkan dari teori kompetensi emosional-sosial oleh Boyatzis dan Goleman pada tahun 2011. Teori dan instrumen yang dikembangkan terdiri atas empat aspek yaitu 1) kesadaran diri; 2) manajemen diri; 3) manajemen hubungan; 4) kesadaran sosial, dari empat aspek tersebut terbagi menjadi 12 sub aspek utama yaitu 1) kesadaran emosi diri; 2) kontrol emosi diri; 3) orientasi berprestasi; 4) berpikiran positif; 5) penyesuaian diri; 6) empati; 7) kesadaran organisasi; 8) pengaruh; 9) mentor; 10) manajemen konflik; 11) pemimpin inspirasional; dan 12) kerja tim. 
Instrumen yang disusun diperuntukan bagi diri (self assesment), serta teman sebaya dan guru. Berdasarkan teori yang menjadi dasar pengembangan instrumen kemudian disusun menjadi kisi-kisi instrumen dan disusun menjadi instrumen utuh yang telah tervalidasi dan teruji keterandalannya.

Instrumen kompetensi emosional-sosial selain penilaian pribadi juga melibatkan penilaian teman sebaya dan guru. Hal ini disebabkan oleh isu data yang bias akibat rendahnya kesadaran diri (Boyatzis \& Goleman, 2011). Prosedur penelitian yang melibatkan penilaian teman sebaya dan guru, harus memenuhi syarat bahwa penilai mengetahui dengan baik keseharian peserta didik berbakat.

Instrumen Kompetensi Emosional-Sosial Penilaian Pribadi tersusun atas 69 item yang ditujukan untuk mengungkap penilaian diri terhadap kompetensi emosional-sosial yang dimiliki. Instrumen Kompetensi Emosional-Sosial Penilaian Teman Sebaya tersusun atas 72 item yang ditujukan untuk mengungkap cara pandang teman terhadap kompetensi emosional-sosial peserta didik berbakat. Instrumen Kompetensi EmosionalSosial Penilaian Guru tersusun atas 56 item yang ditujukan untuk mengungkap cara pandang guru terhadap kompetensi emosional-sosial peserta didik berbakat. Untuk memperoleh data penelitian digunakan skala likert. Setiap pernyataan terdiri dari lima tingkat jawaban yang dikemukakan dalam opsi jawaban SS (Sangat Sesuai), S (Sesuai), CS (Cukup Sesuai), KS (Kurang Sesuai), TS (Tidak Sesuai).

\section{HASIL DAN PEMBAHASAN}

Kompetensi emosional-sosial peserta didik ditinjau dari pencapaian pada setiap sub aspek yaitu 1) kesadaran emosi diri; 2) kontrol emosi diri; 3) orientasi berprestasi; 4) berpikiran positif; 5) penyesuaian diri; 6) empati; 7) kesadaran organisasi; 8) pengaruh; 9) mentor; 10) manajemen konflik; 11) pemimpin inspirasional; dan 12) kerja tim.

Temuan dari penelitian memperoleh data dari penilaian pribadi, teman sebaya, dan guru. Berdasarkan penilaian pribadi, hasil penelitian menunjukkan pencapaian kompetensi emosional-sosial dengan pencapaian terendah sampai tertinggi secara berturut-turut adalah: (1) sub aspek kerja tim dengan tingkat pencapaian 53,06\%; (2) sub aspek pengaruh dengan tingkat pencapaian $54,42 \%$; (3) sub aspek berpikir positif dengan tingkat pencapaian $56,32 \%$; (4) sub aspek kesadaran emosi diri dengan tingkat pencapaian 58,97\%; (5) sub aspek kesadaran organisasi dengan tingkat pencapaian 61,98\%; (6) sub aspek penyesuaian diri dengan tingkat pencapaian $62,02 \%$; (7) sub aspek pemimpin inspirasional dengan tingkat pencapaian 63,08\%; (8) sub aspek kontrol emosi diri dengan tingkat pencapaian $65,81 \%$ (9) sub aspek orienatsi berprestasi dengan tingkat pencapaian 66,40\%; (10) sub aspek mentor dengan tingkat pencapaian 67,09\%; (11) sub aspek manajemen konflik dengan tingkat pencapaian $67,88 \%$; (12) sub aspek empati dengan tingkat pencapaian $70,15 \%$.

Berdasarkan penilaian teman sebaya dengan pencapaian terendah sampai tertinggi secara berturut-turut adalah: (1) sub aspek kontrol emosi diri dengan tingkat pencapaian 60,81\%; (2) sub aspek mentor dengan tingkat pencapaian 61,37\%; (3) sub aspek kesadaran emosi diri dengan tingkat pencapaian 63,25\% (4) sub aspek manajemen konflik dengan tingkat pencapaian $65,10 \%$; (5) sub aspek pemimpin inspirasional dengan tingkat pencapaian 65,81\%; (6) sub aspek kerja tim dengan tingkat pencapaian 65,95\%; (7) sub aspek orientasi berprestasi dengan tingkat pencapaian $66,77 \%$; (8) sub aspek pengaruh 
dengan tingkat pencapaian 67,18\%; (9) sub aspek berpikir positif dengan tingkat pencapaian $69,09 \%$ (10) sub aspek kesadaran organisasi dengan tingkat pencapaian 69,35\%; (11) sub aspek empati dengan tingkat pencapaian 69,37\%; (12) sub aspek penyesuaian diri dengan tingkat pencapaian $72,36 \%$.

Berdasarkan penilaian teman sebaya dengan pencapaian terendah sampai tertinggi secara berturut-turut adalah: (1) sub aspek pengaruh dengan tingkat pencapaian $65,20 \%$; (2) sub aspekpenyesuaian diri dengan tingkat pencapaian $66,15 \%$; (3) sub aspek mentor dengan tingkat pencapaian $67,95 \%$ (4) sub aspek kesadaran emosi diri dengan tingkat pencapaian $68,80 \%$; (5) sub aspek pemimpin inspirasional dengan tingkat pencapaian $71,15 \%$; (6) sub aspek berpikir positif dengan tingkat pencapaian 71,62\%; (7) sub aspek kontrol emosi diri dengan tingkat pencapaian 73,40\%; (8) sub aspek kesadaran organisasi dengan tingkat pencapaian 75,06\%; (9) sub aspek orientasi berprestasi dengan tingkat pencapaian $76,37 \%$ (10) sub aspek kerja tim dengan tingkat pencapaian $77,29 \%$; (11) sub aspek manajemen konflik dengan tingkat pencapaian $77,56 \%$; (12) sub aspek empati dengan tingkat pencapaian $82,69 \%$.

Perolehan data dari penilaian pribadi, teman sebaya dan guru, diolah melalui pengujian rata-rata uji ANOVA, yang memperoleh nilai signifikansi sebesar sebesar 0,022. Nilai signifikan $(\mathrm{p})<0,055$ menunjukkan hasil data yang tidak signifikan. Pada hasil uji yang dilakukan $0,022<0,055$ menunjukkan bahwa terdapat perbedaan penilaian peserta didik berbakat dari tiga penilai yaitu pribadi, teman sebaya, dan guru. Secara lebih rinci perbedaan signifikan antara tiga penilai diperoleh hasil (1) data menurut penilaian pribadi dengan data menurut penilaian teman sebaya menunjukkan angka signifikan 0,163 , itu berarti $p>0,05$. Angka 0,163 $>0,05$ menunjukkan bahwa dari dua data yang dikumpulkan tidak menunjukan perbedaan; (2) data menurut penilaian pribadi dengan data menurut penilaian guru menunjukkan angka signifikan 0,000 , itu berarti $p<0,05$. Angka 0,000 <0,05 menunjukkan bahwa dari dua data yang dikumpulkan menunjukkan adanya perbedaan; (3) data menurut penilaian teman sebaya dengan data menurut penilaian guru menunjukkan angka signifikan 0,025 , itu berarti $p<0,05$. Angka $0,025<0,05$ menunjukkan bahwa dari dua data yang dikumpulkan menunjukkan adanya perbedaan; (4) berdasarkan temuan tersebut penilaian pribadi dengan teman sebaya tidak menunjukkan perbedaan. Akan tetapi, penilaian guru dengan penilaian pribadi dan penilaian teman sebaya menunjukkan perbedaan.

Hasil temuan penelitian berdasarkan penilaian pribadi, teman sebaya, dan guru terhadap peserta didik berbakat di kelas X SMA Negeri 4 Bandung Tahun Ajaran 2015/206 pada umumnya menunjukan bahwa kompetensi emosional-sosial peserta didk berada pada kategori pencapaian kompeten. Peserta didik pada kategori kompeten diasumsikan telah mencapai tingkat kompetensi emosional-sosial kompeten pada setiap aspeknya, yaitu kompetensi emosional-sosial dengan menjalin hubungan dengan lingkungan secara efektif yang diwujudkan dalam kemampuan (1) memahami diri, (2) mengontrol emosi diri, (3) berorientasi berprestasi, (4) berpikiran positif, (5) kemampuan menyesuaikan diri, (6) berempati, (7) kesadaran berorganisasi, (8) kemampuan memberikan pengaruh, (9) kemampuan menjadi mentor, (10) kemampuan menyelesaikan konflik, dan (11) kemampuan bekerjasama dalam tim, dengan kata lain peserta didik pada kategori ini memiliki kompetensi emosional-sosial yang kompeten.

Pada hasil penelitian yang mengaitkan pada kompetensi emosional-sosial ditemukan bahwa kompetensi emosional-sosial peserta didik berbakat kelas X SMA 
Negeri 4 Bandung tahun ajaran 2015/2016 secara umum pencapaian rata-rata peserta didik ada pada tingkatan kompeten. Secara lebih menyeluruh hasil penelitian melibatkan penilaian teman sebaya dan guru, sebagai individu yang terlibat langsung berinteraksi dengan peserta didik di sekolah. Berdasarkan hasil temuan, ditemukan bahwa secara umum penilaian teman sebaya dan diri tidak menunjukan perbedaan, akan tetapi hasil penelitian menunjukkan bahwa penilaian guru terhadap peserta didik berbakat menunjukan hasil yang berbeda baik dengan penilaian diri atau pun penilaian teman sebaya. Berdasarkan hasil temuan tersebut diperlukan kajian yang lebih mendalam lagi mengenai interaksi peserta didik dengan guru pada lingkup lingkungan sekolah sebagai upaya proses pendidikan mengembangkan potensi peserta didik.

Bagaimana pun bentuk interaksi peserta didik di sekolah terhadap teman sebaya dan guru, lingkungan sekolah yang kondusif dan saling mendukung perkembangan peserta didik sangatlah dibutuhkan, karena masa remaja adalah masa penuh banyak tantangan, karena remaja dituntut untuk banyak menyesuaikan dengan banyak perubahan. Hurlock (1980) menyebutkan bahwa perkembangan fisik yang cepat dan penting disertai dengan cepatnya perkembangan mental pada masa awal remaja, maka akan diperlukan penyesuaian mental dan perlunya membentuk sikap, nilai, dan minat.

Perkembangan kompetensi emosional-sosial peserta didik berbakat kelas X SMA Negeri 4 Bandung Tahun Ajaran 2015/2016 berdasarkan hasil penelitian, ditemukan bahwa ketercapaian perkembangan pada aspek kesadaran diri adalah pencapaian terendah baik dari penilaian diri, teman sebaya, dan guru. Kesadaran diri adalah terkait dengan kemampuan individu dalam membangun kesadaran emosi diri yang ditunjukkan dengan kemampuan dalam memahami emosi yang dirasakan dan memahami bagaimana emosi-emosi tersebut berdampak terhadap pekerjaan.

Masa remaja awal yang berakhir pada usia 16 tahun adalah masa dimana remaja awal memasuki lingkungan baru yaitu sekolah dijenjang SMA. Tantangan yang dihadapi oleh remaja adalah adanya tuntutan-tuntutan dan tanggung jawab baru di sekolah. Hurlock (1980) menyebutkan bahwa sebagian besar remaja mengalami ketidakstabilan dari waktu ke waktu sebagai konsekuensi dari usaha penyesuaian diri pada pola perilaku baru dan harapan sosial yang baru. Usaha pemahaman emosi yang dirasakan sebagai bentuk upaya pengendalian emosi dan diri dapat memberikan manfaat dan dampak yang positif terhadap pekerjaan. Pemahaman emosi adalah suatu proses kematangan emosi yang harus dipelajari oleh remaja sebagai cara memahami dan memperoleh gambaran tentang situasi-situasi yang dapat menimbulkan reaksi emosional. Menurut Hurlock (1980) cara yang tepat dapat dipelajari remaja adalah dengan membicarakan berbagai masalah pribadinya dengan orang lain. Belajar lebih terbuka terhadap perasaan dan masalah pribadi untuk diceritakan kepada orang yang dapat dipercayai.

Proses pengembangan kompetensi emosional-sosial sangatlah jelas akan membutuhkan faktor-faktor dukungan dari lingkungan peserta didik. Dalam hal ini peserta didik yang berada di sekolah, banyak menghabiskan waktu dengan berinteraksi dengan guru dan teman. berbakat. Sikap guru kepada peserta didik berbakat tidak hanya berpengaruh terhadap performa kerja peserta didik berbakat akan tetapi juga berpengaruh kepada keefektifan program bagi peserta didik berbakat di sekolah. 


\section{SIMPULAN}

Kompetensi emosional-sosial peserta didik berbakat kelas X SMA Negeri 4 Bandung Tahun Ajran 2015/2016 beradap pada kategori kompeten. Pencapaian kompetensi emosional-sosial peserta didik berbakat pada tingkatan kompeten menunjukkan bahwa peserta didik telah dapat menjalin hubungan dengan lingkungan secara efektif yang diwujudkan dalam kemampuan memahami diri, mengontrol emosi diri, berorientasi berprestasi, berpikiran positif, kemampuan menyesuaikan diri, berempati, kesadaran berorganisasi, kemampuan memberikan pengaruh, kemampuan menjadi mentor, kemampuan menyelesaikan konflik, dan kemampuan bekerjasama dalam tim, dengan kata lain peserta didik pada kategori ini memiliki kompetensi emosional-sosial yang kompeten. Pada penelitian pelibatan penilaian kompetensi peserta didik berbakat tidak hanya berdasar kepada penilaian pribadi, akan tetapi juga penilaian guru dan teman sebaya.

Persepsi guru dan teman sebaya kepada peserta didik berbakat terhadap kompetensi emosional-sosial peserta didik berbakat dapat mempengaruhi persepsi peserta didik berbakat terhadap kompetensi emosional-sosial yang dimilikinya. Ekspektasi lingkungan sekitar kepada peserta didik berbakat dapat menjadi tantangan tersendiri bagi peserta didik berbakat, untuk menghadapi segala tantangan yang dihadapi, peserta didik berbakat memerlukan kesadaran diri untuk selalu mengembangkan diri dan meningkatkan kompetensi emosional-sosial sebagai modal bersosialisasi dengan lingkungan sekitar.

Dalam lingkungan pendidikan formal peran pendidik di sekolah adalah senantiasa membantu peserta didik untuk mencapai tugas perkembangan yang dimilikinya, dengan segala keunikan dan pencapaian tugas perkembangan yang berbeda menunjukan bahwa kebutuhan peserta didik tidak dapat diseragamkan. Populasi peserta didik dengan keberbakatan yang dimilikinya tetap perlu diakomdasi untuk memaksimlakan potensi yang dimiliki. Mengacu kepada penelitian mengenai kompetensi emosional-sosial peserta didik berbakat kela X SMA Negeri 4 Bandung disusunlah rancangan program bimbingan dan konseling pribadi-sosial untuk meningkatkan kompetensi emosional-sosial peserta didik berbakat. Dengan disusunnya program tersebut diharapkan peserta didik berbakat dapat meningkatkan kompetensi emosional-sosial yang dimiliki peserta didik berbakat.

\section{REFERENSI}

Boyatzis, R. E., \& Goleman, D. (2011). Emotional and social competency inventory. Philadelphia, PA: Hay Group.

Callahan, C \& Miller, E. (2005). A child responsive model of giftedness. Dalam J. S. Robert \& E. D. Janet (Eds.), Conception of giftedness (pp. 38-51). Cambridge, UK: Cambridge University Press.

Coleman, L. J., \& Cross, T. L. (1988). Is being gifted a social handicap?. Journal for the Education of the Gifted, 11(4), 41-56.

Departemen Pendidikan dan Kebudayaan. (2014). Peraturan menteri pendidikan dan kebudayaan Republik Indonesia no. 111 tahun 2014. Jakarta: Depdikbud. 
Džinović, V., Đević, R., \& Đerić, I. (2019). The role of self-control, self-efficacy, metacognition, and motivation in predicting school achievement. Psihologija, 52(1), $35-52$

Gallagher, S., Smith, S. R., \& Merrotsy, P. (2011). Teachers' perceptions of the socioemotional development of intellectually gifted primary aged students and their attitudes towards ability grouping and acceleration. Gifted and Talented International, 26(1-2), 11-24.

Herrmann, A., \& Nevo, B. (2011). Gifted education in German-speaking countries. Gifted and Talented International, 26(1-2), 47-62.

Hurlock, E. (1980). Psikologi perkembangan. Jakarta: Erlangga.

Mirnics, Z., Heincz, O., Bagdy, G., Surányi, Z., Gonda, X., Benko, A., ... \& Juhasz, G. (2013). The relationship between the big five personality dimensions and acute psychopathology: Mediating and moderating effects of coping strategies. Psychiatria Danubina, 25(4), 0-388.

Surya, M. (2003). Psikologi konseling. Bandung: Pustaka Bani Quraisy. 